\title{
ANALISIS EFISIENSI KETERSEDIAAN AIR BAKU DENGAN KONSEP SAVING RECYCLING PADA GEDUNG APARTMENT GRAND TAMAN MELATI 2
}

\author{
Indra Hilmi Fauzan ${ }^{1, \nabla)}$, Andi Tenrisuki Tenriajeng ${ }^{2)}$ \\ 1.2 Universitas Gunadarma, Teknik Sipil, Jl. Margonda Raya No.100, Depok

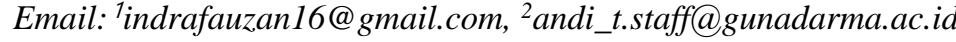

\begin{abstract}
It is the main and important element to be fulfilled, water becomes the primary need in all elements life of living things so that they can continue to live life and all activities. Besides that water also secondary needs as means of transportation. Even, water also become a recreational facility so that water can also be said as complement to tertiary needs. Water covered almost $71 \%$ on lining of the Earth's surface. About 1.4 trillion cubic kilometers (330 million miles) has been available on the Earth. Viewed from the point of view of public health, the average volume of water requirements for each individual/day ranges from 150-200 liters or 35-40 gallons. Water requirements vary and depend on the climate, living standards and habits of the people. Reduced population of vacant land results in the availability of land be reduced and limited. This makes the opportunity for hotel and apartment properties to increase. For some large cities, the presence of hotels and apartments increased every year, finally it give impact on needs and availability of clean water that must be available every day. Because this research is very important to make an effort that able to minimize using of ground water by saving water and recycling water methods. The effort able to be a solution to the efforts to create efficient use of ground water. Exactly this Water Management Infrastructure Engineering is carried out in the Grand Taman Melati Margonda Apartment 2. With total unit reaching 939 units. Aspects that are the focus of results of this study are aspects of quantity and cost. The implementation of the method used in this research is concept of saving in rainwater and recycling used water. the percentage value resulting from the research table simulation obtained $58.157 \%$ for water saving efficiency.
\end{abstract}

Keywords : Efficiency, Recycling water, Saving water, Water

\begin{abstract}
Abstrak
Air adalah elemen utama dan penting yang harus dipenuhi, air menjadi kebutuhan utama dalam semua elemen kehidupan makhluk hidup sehingga mereka dapat terus menjalani kehidupan dan semua aktivitasnya. Selain itu air juga menjadi kebutuhan sekunder sebagai alat transportasi. Bahkan air juga bisa menjadi sarana rekreasi sehingga air juga bisa dikatakan sebagai pelengkap kebutuhan tersier. Air menutupi hampir $71 \%$ dari permukaan bumi. Ada 1,4 triliun kilometer kubik atau sekitar (330 juta mil) tercatat yang tersedia di Bumi. Dilihat dari sudut pandang kesehatan masyarakat, volume rata-rata untuk angka kebutuhan air masing-masing individu per hari mencapai kisaran 150-200 liter atau sekitar 35-40 galon. Kebutuhan air memang selalu beragam dan akan tergantung pada iklim, aspek standar atau pola hidup serta kebiasaan hidup masyarakat. Berkurangnya populasi lahan kosong menyebabkan ketersediaan lahan menjadi berkurang dan terbatas. Ini membuat peluang untuk properti hotel dan apartemen meningkat. Untuk beberapa kota besar, keberadaan hotel dan apartemen semakin meningkat setiap tahunnya, tentu saja ini akan berdampak pada kebutuhan dan ketersediaan air bersih yang harus tersedia setiap hari. Penelitian ini berisi upaya untuk meminimalkan penggunaan air tanah dengan menghemat air dan metode daur ulang air. Upaya ini diharapkan mampu menjadi solusi dalam menciptakan efisiensi penggunaan air tanah. Penelitian ini dilakukan di Apartemen Grand Taman Melati Margonda 2. Dengan total unit mencapai 939 unit. Aspek yang menjadi fokus hasil penelitian ini adalah aspek kuantitas dan biaya. Implementasi metode yang digunakan dalam penelitian ini adalah dengan konsep saving pada air hujan dan recycling pada air bekas. nilai persentase yang dihasilkan dari simulasi tabel penelitian didapat $58,157 \%$ untuk efisiensi penghematan air.
\end{abstract}

Kata Kunci : Efisiensi, Recycling water, Saving water, Air 


\section{PENDAHULUAN}

\section{Latar Belakang}

Salah satu sumber daya alam yang menjadi penunjang dan pelengkap kebutuhan pokok bagi manusia adalah air. Bumi merupakan satu-satunya planet yang mengandung unsur air. Klasifikasi air mayoritas terdiri dari air air asin yang secara unsur kimiawi tidak dapat dikonsumsi secara langsung. Air tawar memiliki volume yang cukup rendah dibandingkan dari total air bumi, yakni hanya mencapai 2,5\% dari keseluruhan lapisan air di bumi. Keterbatasan akan kebutuhan sumber daya air bersih secara global akhirnya menyebabkan kelangkaan air di seluruh benua.

Upaya yang paling potensial dalam mengatasi pengurangan konsumsi air tanah adalah salah satunya dengan memanfaatkan air hujan dan air bekas sebagai solusi untuk meminimalisir daya dukung tanah akibat penggunaan air tanah yang dilakukan secara berlebih dan terus menerus.

Tercatat bahwa kota Jakarta pada tahun 2010 menyatakan terkait konsumsi akan kebutuhan air untuk per kapita di Jakarta sebesar 78 liter/harinya, ini dikatakan cukup baik jika dibandingkan dengan rata-rata 22 dari kota di benua Asia lainnya yang mencapai (278 liter/orang/hari). Dalam hal tersebut tidak mendeskripsikan keadaan secara general. Namun, ini hanya sekedar mewakili dari total volume air yang di distribusikan melalui jalur dan saluran pipa yang kemudian dijual oleh perusahaan air dipastikan tidak memenuhi $46 \%$ dari total kebutuhan air yang ada di Jakarta. Sementara hamper sekitar 70\% pada kategori domestik / rumah tangga mayoritas bergantung pada ketersediaan air tanah. Maka dari itu, penelitian ini bermaksud untuk memberikan langkah yang solutif untuk mengurangi tingkat penggunaan air tanah.

\section{Tujuan Penulisan}

Tujuan penulisan Tugas Akhir antara lain sebagai berikut :

1. Menentukan kebutuhan air (liter) perkapita untuk skala waktu tertentu (Harian/Bulan).

2. Menghitung volume bak reservoir PAH untuk saving water.

3. Menentukan neraca simulasi perbandingan antara supply dan demand air baku pada bak PAH.

4. Menentukan distribusi air baku dari suplai saving water dan recycling water.

5. Menentukan efisiensi dalam aspek kuantitas dan biaya dari supply air dengan rencana konsep saving water dan recycling water.

\section{Lokasi Perencanaan}

Apartemen Grand Taman Melati Margonda terletak di Jalan Margonda Raya kav 525, Kios k 15 Apartemen Grand Taman Melati 2 Margonda, Pondok Cina, Beji, Depok, Jawa Barat, 16424.

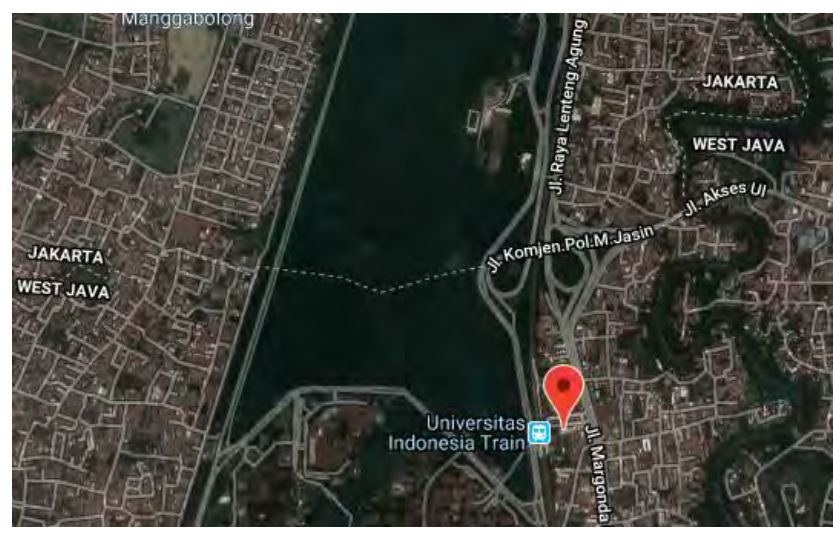

Gambar 1. Peta Lokasi

\section{Tinjauan Pustaka}

a. Air

Setiap makhkluk hidup akan bergantung pada air. Senyawa netral ini memiliki 
unsur zat yang berperan sebagai pelarut pada proses mekanisme metabolism tubuh. Maka dari itu air menjadi kebutuhan primer yang harus dipenuhi setiap waktunya. Agar keberlangsungan makhluk hidup dapat tetap terjaga.

b. Siklus Air

Berikut ini adalah gambar siklus hidrologi beserta urutan peristiwanya :

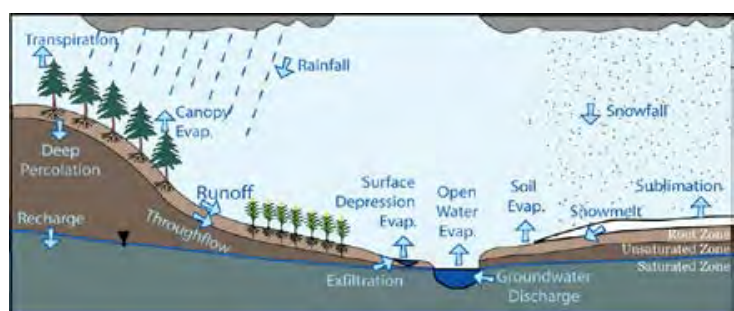

Gambar 2. Siklus Hidrologi

\section{Teknik Distribusi dan Kebutuhan Air} pada Gedung

Berikut masing-masing sistem

pengaliran distribusi air bersih :

1. Cara Gravitasi

2. Cara Pemompaan

3. Cara Gabungan

Berikut adalah tabel pemakaian air dingin minimum sesuai penggunaan gedung :

Tabel 1. Pemakaian air dingin minimum penggunaan gedung

\begin{tabular}{|c|c|c|}
\hline $\begin{array}{l}\text { Penggunaan } \\
\text { Gedung }\end{array}$ & Pemakaian Air & Satuan \\
\hline Rumah Tinggal & 120 & Liter/penghuni/hari \\
\hline Rumah Susun & 100 & Liter/penghuni/hari \\
\hline Asrama & 120 & Liter/penghuni/hari \\
\hline Rumah Sakit & 500 & $\begin{array}{l}\text { Liter/tempat tidur } \\
\text { pasien/hari }\end{array}$ \\
\hline Sekolah Dasar & 40 & Liter/siswa/hari \\
\hline SLTP & 50 & Liter/siswa/hari \\
\hline $\begin{array}{l}\text { SMU/SMK dan } \\
\text { lebih tinggi }\end{array}$ & 80 & Liter/siswa/hari \\
\hline Ruko/Rukan & 100 & $\begin{array}{l}\text { Liter/penghuni dan } \\
\text { pegawai/ hari }\end{array}$ \\
\hline Kantor/Pabrik & 50 & $\begin{array}{l}\text { Liter/penghuni dan } \\
\text { pegawai/ hari }\end{array}$ \\
\hline $\begin{array}{l}\text { Toserba, toko } \\
\text { pengecer }\end{array}$ & 5 & Liter/m2 \\
\hline Restoran & 15 & Liter/Kursi \\
\hline Hotel berbintang & 250 & Liter/tempat tidur/hari \\
\hline $\begin{array}{c}\text { Hotel } \\
\text { Melati/Penginapa } \\
\mathrm{n}\end{array}$ & 150 & Liter/tempat tidur/hari \\
\hline $\begin{array}{l}\text { Gd. Pertunjukan, } \\
\text { Bioskop }\end{array}$ & 10 & Liter/kursi \\
\hline Gd. Serba Guna & 25 & Liter/kursi \\
\hline
\end{tabular}

\begin{tabular}{ccc}
\hline Stasiun, terminal & 3 & $\begin{array}{c}\text { Liter/penumpang tiba } \\
\text { dan pergi } \\
\text { Peribadatan }\end{array}$ \\
\hline
\end{tabular}

Sumber :

a. Hasil pengkajian Puslitbang Permukiman Dep. Kimpraswil tahun 2000.

b. Permen Kesehatan RI No : 986/Menkes/Per/XI/1992

Persamaan yang digunakan untuk menentukan perhitungan kebutuhan air bersih didalam infrastruktur gedung yakni sebagai berikut :

- Kebutuhan rata-rata pemakaian / hari

$\mathrm{Qh} \quad=$

Qd/t.......................(1)

$\mathrm{Qh} \quad=$ pemakaian air rata-rata

(l/jam)

Qd =pemakaan air rata-rata (l/hari)

$\mathrm{t}=$ pemakaian rata-rata

(jam/hari)

Qh-Mx = C1 x Qh.

Dimana:

Qh-maks = pemakaian air (l/jam)

$\mathrm{C} 1$ = konstata 1,5 untuk bangunan

rumah, tinggal, 1,75 untuk bangunan

perkantoran, 2,0 untuk bangunan

hotel/apartement.

- Dihitung besarnya volume bak air bawah :

Volume GWT [Qd - (Qs x t)] x T..(8)

Dimana:

Qd = pemakaian air rata-rata (m3/jam).

Qs = kapasitas pipa dinas (m3/jam).

$\mathrm{t}=$ pemakaian air 1 hari (jam/hari).

$\mathrm{T}=$ waktu penampungan (hari)

\section{Perhitungan Tangki Atap (Roof} Tank) Penampung Air

$\mathrm{VE}=|(\mathrm{Qp}-\mathrm{Qmax})| \mathrm{x} \mathrm{Tp}+\mathrm{Qpu} \mathrm{x}$

Tpu.....(3)

keterangan :

VE : kapasitas efektif tangki atas (L)

Qp : kebutuhan jam puncak (L/menit)

Qmax : kebutuhan menit puncak

(L/menit)

Qpu : kapasitas pompa pengisi (L/menit) 
Tp : jangka waktu kebutuhan puncak (menit)

Tpu : jangka waktu kerja pompa pengisi (menit)

\section{Perhitungan Suplai Air}

Menentukan angka volyume untuk suplai/ketersediaan air yang diperoleh dari penampungan jumlah air hujan yang tertangkap pada bangunan penangkap air hujan dapat dihitung melalui rumus persamaan (Permen PU, 2009) seperti dibawah ini :

$\mathrm{V}=\mathrm{R} \times \mathrm{A} \mathrm{x}$

Dimana:

$\mathrm{V}=$ Volume Air tertampung (m3/bulan)

$\mathrm{R}=$ Curah hujan (m/bulan)

$\mathrm{A}=$ Luas daerah tangkapan (m2)

$\mathrm{k}=$ Koofisien Runoff

\section{c. Air PDAM}

Perusahaan Daerah Air Minum (PDAM) berperan aktif sebagai unit pengembang usaha milik daerah dalam kegiatan distribusi air bersih bagi masyarakat umum di masing-masing daerah.

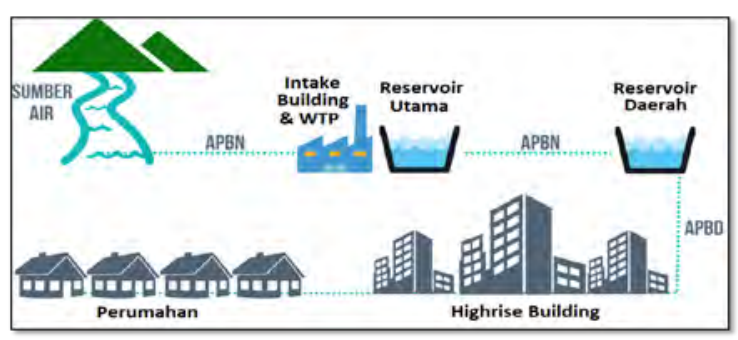

Gambar 3. Proses singkat alur distribusi air PDAM

d. Air Tanah (Deepwell)

Umumnya kedalam air tanah (deepwell) ini berada di kedalaman mencapai hingga 200 meter dibawah lapisan batu-batuan yang bersifat impermeable.

\section{e. $\quad$ Saving Water}

Bak penampung air hujan (PAH) merupakan infrastruktur penampung air yang bias menjadi solusi dalam menyimpan ketersediaan air yang disuplai dari air hujan.

\section{f. $\quad$ Recycling Water}

Secara general, teknik dalam mengolah air bersih terdiri dari 3 aspek atau unsur, yakni terdiri dari unsur kimiawi, fisika dan biologi. Dalam teknik mengolah secara sistem kimiawi seringkali menggunakan material/bahan seperti klor, jenis tawas dan bahan lain yang memiliki sifat menyerap (absorpsi).

\section{Metodologi Penelitian \\ Diagram Alur Perencanaan}

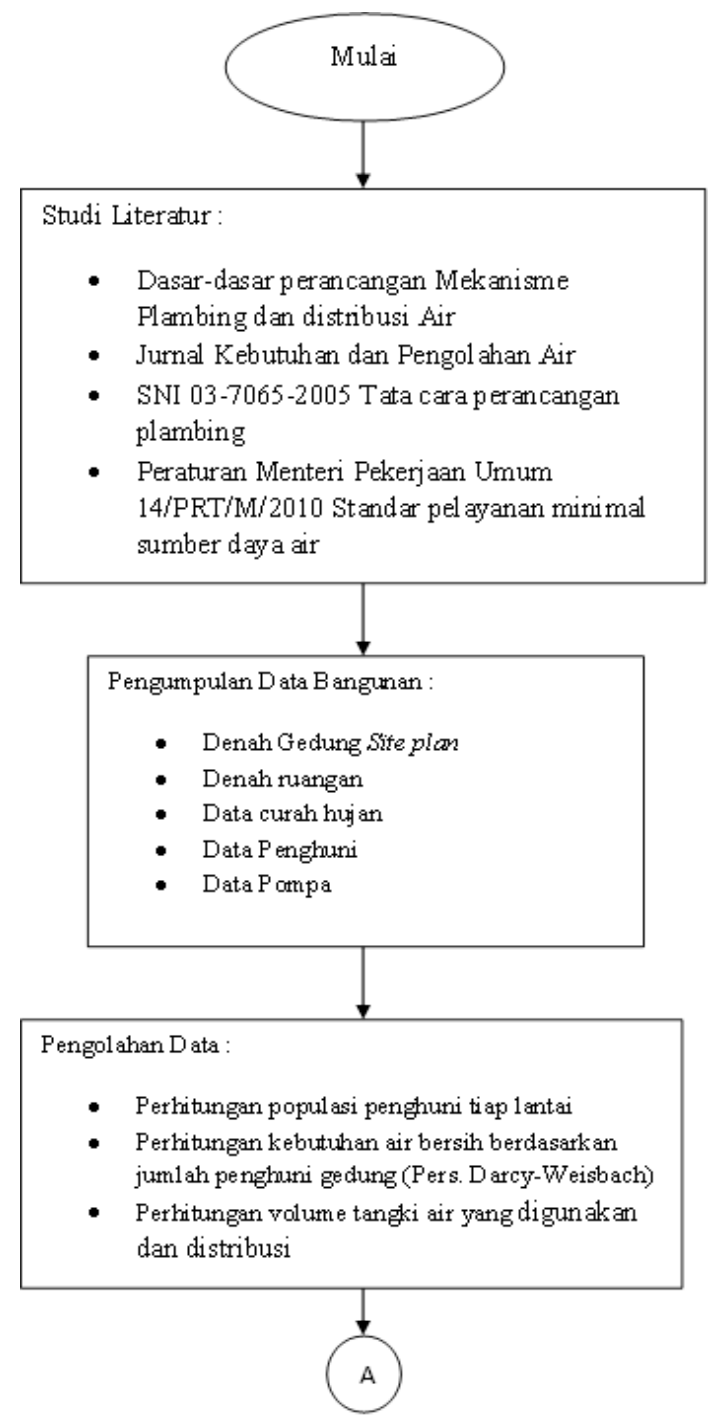

Gambar 4. Diagram Alur Perencanaan - A 


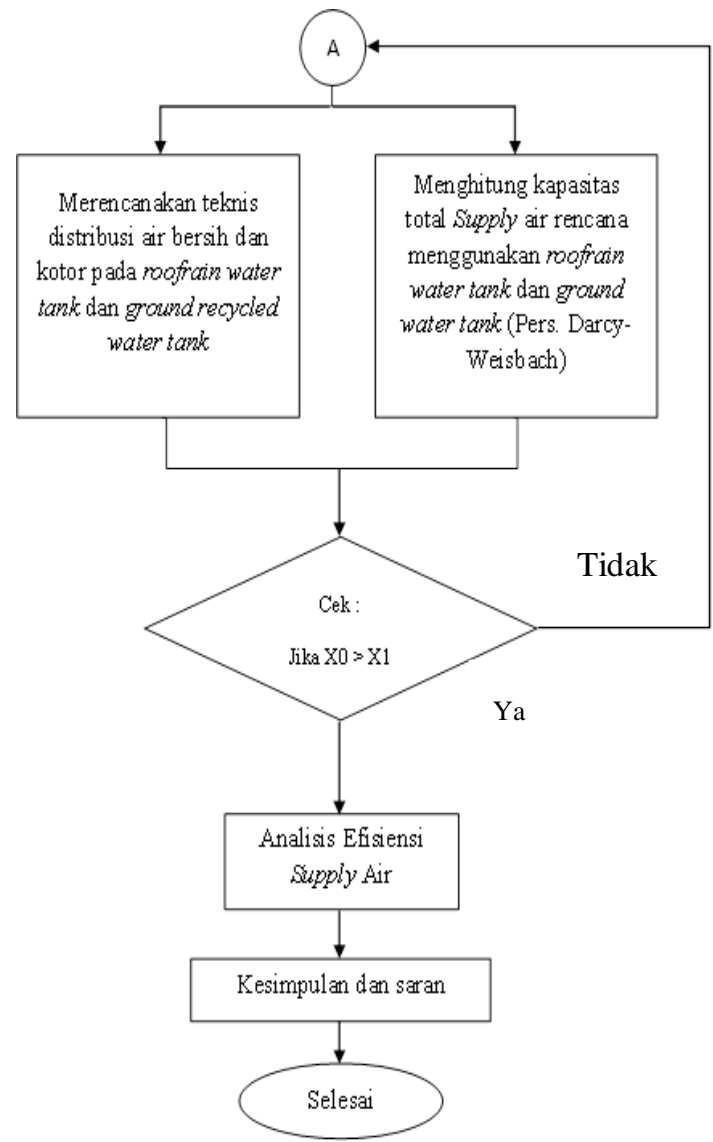

Gambar 5. Diagram Alur Perencanaan - B

Diagram alur penulisan ini dimulai dengan mengumpulkan literatur dan menyiapkan berbagai referensi serta peraturan yang berkaitan dengan penelitian tersebut. Lalu dilanjutkan dengan pengumpulan data sebagai bahan kajian dan penelitian yang kemudian akan diolah berdasarkan peraturan dan prosedur yang sudah ditetapkan baik secara nasional maupun internasional. Pembahasan ini akan terbelah menjadi dua yakni menentukan secara teknis untuk dimensi dan volume, serta menentukan skema distribusi masing-masing jalur aliran air. Dari kedua pokok pembahasan tadi kemudian dapat ditentukan untuk menghitung analisis efisiensi yang diperoleh baik dalam segi biaya maupun segi persentase kuantitas yang diperoleh.

\section{Hasil Dan Pembahasan \\ Data Perencanaan}

- Data Bangunan Denah (Lampiran)

- Data Curah Hujan (Lampiran)

Curah hujan rata-rata (t) lima tahun

$=\frac{\mathrm{x} 1+\mathrm{x} 2+\mathrm{X} 3+\mathrm{x} 4+\mathrm{x} 5}{\mathrm{t}}$

$=\frac{22,37+18,46+26,45+20,27+21_{2}, 92}{5}$

$=21,89 \mathrm{~mm}$

Sehingga didapat nilai rata-rata curah hujan harian dalam kurun waktu lima tahun adalah 21,89 mm.

- Data Penghuni

Diketahui :

- $\quad$ Jumlah penghuni $=1.200$ penghuni

- $\quad$ Pemakaian air $=100$

liter/hari/penghuni

Sehingga jumlah total pemakaian air rata-rata penghuni dalam satu gedung apartemen adalah : Jumlah penghuni x Pemakaian air rata-rata perhari/penghuni

- $\quad 1.200$ x $100=120.000$ liter/hari

\section{Perencanaan}

Perencanaan dan Penentuan Ukuran Bak Air Bawah, Bak Air Atas dan Bak Penampung Air Hujan (Saving Water)

1). Untuk menentukan ukuran bak air bawah dan air atas, sebelumnya harus mengetahui jumlah kebutuhan air bersih dengan persamaan berikut :

Qd = Jumlah penghuni $\mathrm{x}$ pemakaian air per orang per hari

Qd $=1.200$ orang $\mathrm{x} \quad 100$

liter/hari/orang

$\mathrm{Qd}=120.000$ liter/hari

$\mathrm{Qd}=120 \mathrm{~m}^{3} / /$ hari

\section{Penentuan Ukuran Bak Air Bawah}

Untuk items (Ground Water Tank) dapat ditentukan perhitungannya dengan 
persamaan sebagai berikut :

1). Terhitung dari besarnya kapasitas pipa dinas dengan persamaan sebagai berikut :

Qs $=\frac{2}{3} x Q h$

Dimana :

$\mathrm{Qh}=15.000$ liter/jam

Qs = kapasitas pipa dinas ( $\left.\mathrm{m}^{3} / \mathrm{jam}\right)$

Sehingga :

Qs $=\frac{2}{3} x 15 \frac{\mathrm{m}^{\mathrm{s}}}{\mathrm{jam}}$

$\mathrm{Qs}=10 \mathrm{~m}^{3} / \mathrm{jam}$

2). Penentuan besarnya volume bak air bawah tanah (GWT) dengan menggunakan persamaan dibawah ini :

Volume GWT = [ Qd - (Qs x t) $]$ x T

Dimana :

Qd $=120 \mathrm{~m}^{3} / /$ hari

Qs $=10 \mathrm{~m}^{3} / \mathrm{jam}$

$\mathrm{T}=1$ hari

$\mathrm{t}=8 \mathrm{jam} / \mathrm{hari}$

Sehingga :

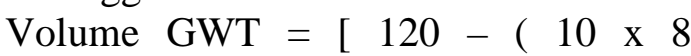
jam/hari ) x 1 hari

$$
\begin{aligned}
& =[120-80] \times 1 \text { hari } \\
& =40 \mathrm{~m}^{3}
\end{aligned}
$$

Diperoleh volume untuk bak air bawah (Ground Water Tank) sebesar $40 \mathrm{~m}^{3}$.

\section{Perhitungan Suplai Air Hujan}

Suplai/ketersediaan air yang didapat dari intensitas air hujan yang tertangkap diatap bangunan yang memiliki dasar perkerasan (pavement) dapat dihitung melalui rumus persamaan (Permen PU, 2009) seperti berikut ini :

$\mathrm{V}=\mathrm{R}$. A . k

Dimana :

$\mathrm{V}=$ Volume Air Tertampung ( $\mathrm{m}^{3} /$ Bulan)

$\mathrm{R}=$ Curah hujan maksimum (m/Bulan)

$\mathrm{A}=$ Luas Daerah tangkapan $\left(\mathrm{m}^{2}\right)$

$\mathrm{K}=$ Koefisien Runoff

\section{Perhitungan pada zona A}

Data yang diperoleh diantaranya :

Curah hujan maksimum dalam periode 5 (lima) tahun $=151.5 \mathrm{~mm}$ (pada tahun 2015)

Luas Area tangkapan $=473,85 \mathrm{~m}^{2}$

Koefisien Runoff $=$ 0,75-0,95 (Untuk area perkerasan/atap berdasarkan

Schwab, et al, 1981, dalam Arsyad, 2006)

$\mathrm{V}=\mathrm{R}$. A . K

$\mathrm{V}=0,1515 \mathrm{~m} \times 473,85 \mathrm{~m}^{2} \times 0,95$

$\mathrm{V}=68,198 \mathrm{~m}^{3}$

\section{Perhitungan pada zona $B$}

Data yang diperoleh diantaranya :

Curah hujan maksimum dalam periode 5 (lima) tahun $=151.5 \mathrm{~mm}$

Luas Area tangkapan $=591,6 \mathrm{~m}^{2}$

Koefisien Runoff $=0,75-0,95$ (Untuk area perkerasan/atap berdasarkan Schwab, et al, 1981, dalam Arsyad, 2006)

$\mathrm{V}=\mathrm{R} \cdot \mathrm{A} \cdot \mathrm{K}$

$\mathrm{V}=0,1515 \mathrm{~m} \times 591,6 \mathrm{~m}^{2} \times 0,95$

$\mathrm{V}=85,146 \mathrm{~m}^{3}$

\section{Perhitungan pada zona $\mathbf{C}$}

Data yang diperoleh diantaranya :

Curah hujan maksimum dalam periode 5 (lima) tahun $=151.5 \mathrm{~mm}$

Luas Area tangkapan $=473,85 \mathrm{~m}^{2}$

Koefisien Runoff $=0,75-0,95$ (Untuk area perkerasan/atap berdasarkan Schwab, et al, 1981, dalam Arsyad, 2006)

$\mathrm{V}=\mathrm{R} \cdot \mathrm{A} \cdot \mathrm{K}$

$V=0,1515 \mathrm{~m} \times 473,85 \mathrm{~m}^{2} \times 0,95$

$\mathrm{V}=68,198 \mathrm{~m}^{3}$

Berdasarkan hasil perhitungan diatas, total volume Bak Penampung Air Hujan pada 3 (tiga) Zona adalah 221,542 $\mathrm{m}^{3}$.

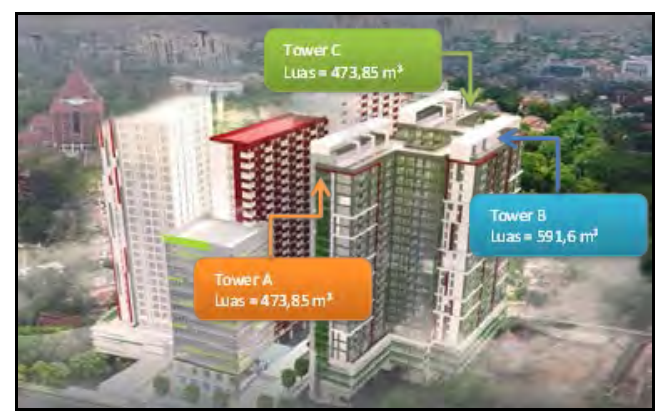

Gambar 6. Luas Area Tangkapan Air Hujan pada Tower A, B dan C 


\section{Hasil Perhitungan Kuantitas Hujan pada Area Luasan Atap}

Perhitungan sample kuantitas hujan dalam waktu satu bulan ini didapatkan dari data curah hujan pada bulan November tahun 2015. Berikut ini adalah rincian volume suplai untuk Tower A dengan luas area tangkapan 473,85 $\mathrm{m}^{2}$, Tower B dengan luas area tangkapan 591,6 $\mathrm{m}^{2}$, dan Tower C dengan luas area tangkapan 473,85 m².

Tabel 2. Perhitungan Kuantitas Hujan pada Tower A

\begin{tabular}{|c|c|c|c|}
\hline Hari & $\begin{array}{l}\text { Curah } \\
\text { Huian } \\
\text { (mm) }\end{array}$ & $\begin{array}{l}\text { Luas } \\
\text { Atgp } \\
\left(\mathrm{m}^{2}\right)\end{array}$ & $\begin{array}{c}\text { Volume } \\
\text { Supply } \\
\left.\text { (m } \mathrm{m}^{2}\right)\end{array}$ \\
\hline 1 & 0 & 473.85 & 0.00 \\
\hline 2 & 0 & 473.85 & 0.00 \\
\hline 3 & 0 & 473.85 & 0.00 \\
\hline 4 & 0 & 473.85 & 0.00 \\
\hline 5 & 0 & 473.85 & 0.00 \\
\hline 6 & 0 & 473.85 & 0.00 \\
\hline 7 & 0 & 473.85 & 0.00 \\
\hline 8 & 0 & 473.85 & 0.00 \\
\hline 9 & 125 & 473.85 & 5.33 \\
\hline 10 & 123 & 473.85 & 5.25 \\
\hline 11 & 38.5 & 473.85 & 16.42 \\
\hline 12 & 0 & 473.85 & 0.00 \\
\hline 13 & 9.8 & 473.85 & 4.18 \\
\hline 14 & 9.6 & 473.85 & 4.09 \\
\hline 15 & 0 & 473.85 & 0.00 \\
\hline 16 & 69.2 & 473.85 & 29.51 \\
\hline 17 & 1.8 & 473.85 & 0.77 \\
\hline 18 & 16.1 & 473.85 & 6.87 \\
\hline 19 & 152 & 473.85 & 6.48 \\
\hline 20 & 73.8 & 473.85 & 31.47 \\
\hline 21 & 0 & 473.85 & 0.00 \\
\hline 22 & 6.5 & 473.85 & 277 \\
\hline 23 & 0 & 473.85 & 0.00 \\
\hline 24 & 0 & 473.85 & 0.00 \\
\hline 25 & 151.5 & 473.85 & 64.61 \\
\hline 26 & 0 & 473.85 & 0.00 \\
\hline 27 & 0.8 & 473.85 & 0.34 \\
\hline 28 & 13.2 & 473.85 & 5.63 \\
\hline 29 & 102 & 473.85 & 4.35 \\
\hline 30 & 13.8 & 473.85 & 5.89 \\
\hline 31 & 0 & 473.85 & 0.00 \\
\hline
\end{tabular}

Simulasi Perhitungan Neraca Air untuk Tangki Penampung Air Hujan Kapasitas 221,542 $\mathrm{m}^{3}$ pada Tahun 2015

Dari perhitungan terkait kapasitas tamping pada tangki, data yang didapat akan digunakan untuk menentukan perhitungan neraca air pada kurun waktu bulan/bulan sebagaimana yang dijelaskan dalam persamaan dan table seperti dibawah ini : Di dapatkan dari persamaan $\mathrm{V}=\mathrm{R}$. A . K. $\mathrm{V}=$ Volume Air Tertampung (m³/Bulan)

$\mathrm{R}=$ Curah hujan maksimum (m/Bulan) $\mathrm{A}=$ Luas Daerah tangkapan $\left(\mathrm{m}^{2}\right)$
$\mathrm{K}=$ Koefisien Runoff

Tabel 3. Nilai suplai berdasarkan nilai curah ujan pada tahun 2015

\begin{tabular}{rr}
\hline Curah Hujan $(\mathrm{mm})$ & Suplai $\left(\mathrm{m}^{3}\right)$ \\
\hline 75.8 & 247.71 \\
125.2 & 215.61 \\
46.6 & 130.64 \\
141.5 & 105.23 \\
36.5 & 201.88 \\
61.5 & 129.09 \\
96.6 & 247.54 \\
104.6 & 121.20 \\
47.8 & 19.23 \\
72.7 & 116.39 \\
45.5 & 260.07 \\
98 & 164.97 \\
\hline
\end{tabular}

Tabel 4. Neraca Air Tangki Tahun 2015

\begin{tabular}{lrrrr}
\hline \multirow{2}{*}{ Bulan } & \multirow{2}{*}{$\begin{array}{l}\text { Suplai } \\
\left(\mathrm{m}^{3}\right)\end{array}$} & Awhun Pertama & & \\
\cline { 3 - 5 }$\left(\mathrm{m}^{3}\right)$ & $\begin{array}{c}\text { Kebutuhan } \\
\left(\mathrm{m}^{3}\right)\end{array}$ & $\begin{array}{c}\text { Akhir } \\
\left(\mathrm{m}^{3}\right)\end{array}$ \\
\hline 1 & 247.71 & 247.71 & 221.54 & 26.17 \\
2 & 215.61 & 241.78 & 221.54 & 20.24 \\
3 & 130.64 & 150.88 & 221.54 & 0.00 \\
4 & 105.23 & 105.23 & 221.54 & 0.00 \\
5 & 201.88 & 201.88 & 221.54 & 0.00 \\
6 & 129.09 & 129.09 & 221.54 & 0.00 \\
7 & 247.54 & 247.54 & 221.54 & 26.00 \\
8 & 121.20 & 147.19 & 221.54 & 0.00 \\
9 & 19.23 & 19.23 & 221.54 & 0.00 \\
10 & 116.39 & 116.39 & 221.54 & 0.00 \\
11 & 260.07 & 260.07 & 221.54 & 38.53 \\
12 & 164.97 & 203.50 & 221.54 & 0.00 \\
Total & 1959.56 & & 2658.50 & \\
\hline
\end{tabular}

Dari simulasi diperoleh suplai air hujan 1959,56 $\mathrm{m}^{3}$ dengan kapasitas daya tampung total dalam kurun waktu satu tahun sebesar 2658,50 $\mathrm{m}^{3}$, sehingga persentase mencapai 73,708 \%. 


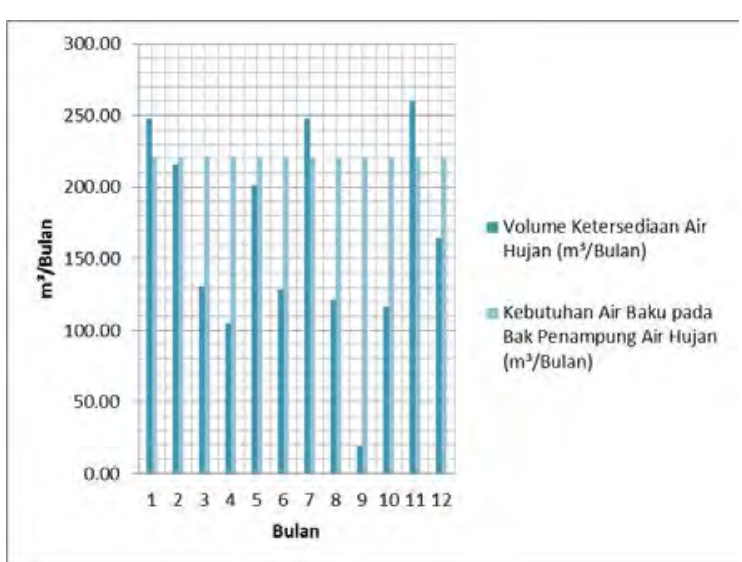

Gambar 7. Diagram Perbandingan Kebutuhan Air Baku dan Ketersediaan Air Hujan di Tahun 2015

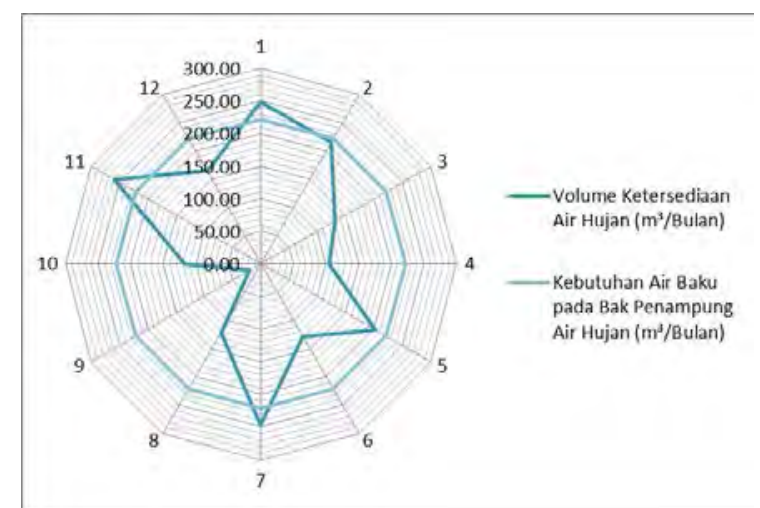

Gambar 8. Grafik Radar Perbandingan Kebutuhan Air Baku dan Ketersediaan Air Hujan di Tahun 2015

\section{Perencanaan Distribusi Air}

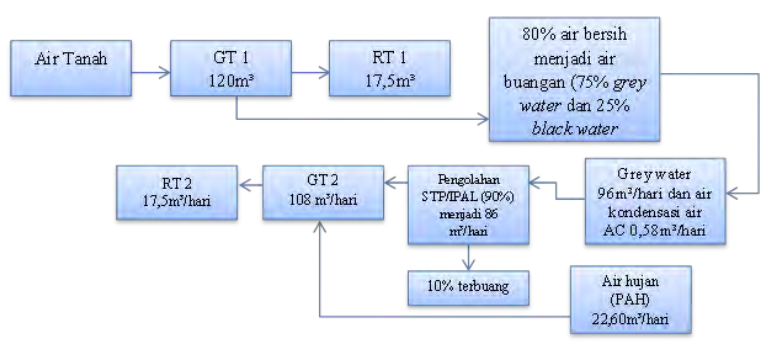

Gambar 9. Skema Distribusi Air

\section{Efisiensi Kuantitas dan Biaya Kuantitas}

a. Saving water

Air hujan yang memiliki potensi dapat dimanfaatkan $=\sum$ kebutuhan air yang sudah terpenuhi di PAH (dalam 5 Tahun) : Total Kebutuhan Air pada PAH selama 5 Tahun

$$
\begin{aligned}
& =1634.77+1347.40+1959.56+ \\
& 1345,85+1443,02 \\
& =7730,60 \mathrm{~m}^{3}: 13.292,5 \mathrm{~m}^{3}
\end{aligned}
$$

$=0,581 \mathrm{~m}^{3}$

Penghematan air PDAM

$=0,581 \times 100 \%$

$=58,157 \%$ dari total kebutuhan air baku PAH.

\section{b. Recycling water}

Total kebutuhan air untuk penghuni apartment sebesar $120 \mathrm{~m}^{3} /$ hari, dengan air buangan $80 \%$ dari $120 \mathrm{~m}^{3} /$ hari yaitu sebesar $96 \mathrm{~m}^{3} /$ hari. Dari unsur air sisa ataupun air terbuang tersebut yakni bernilai $75 \%$ disebut grey water dengan nilao sebesar $72 \mathrm{~m}^{3} /$ hari dan $25 \%$ merupakan black water sebesar 24 $\mathrm{m}^{3} /$ hari. Air yang berasal dari Kondensasi AC, air buangan (grey water) ditampung kemudian masuk pada unit pengolahan dan digunakan kembali untuk keperluan penggelontoran WC dan Dari system tersebut air yang dihemat (digunakan kembali) yaitu air yang berasal dari buangan (grey water), air kondensasi AC sebesar $96 \mathrm{~m}^{3} / \mathrm{hari}$ dan air hujan 22,60 $\mathrm{m}^{3} / \mathrm{hari}$ yang ditampung dengan total sebesar 108 $\mathrm{m}^{3} /$ hari volume ground tank 2 sehingga air yang dapat dihemat sekitar $80 \%$ dari total kebutuhan air bersih.

\section{Biaya}

\section{a. Saving water}

Secara segi biaya, dampak penghematan air bersih apabila di lakukan perbandingan dengan supai PDAM maka diperoleh nilai sebesar berdasarkan pada perhitungan dibawah ini :

$=7730,60 \mathrm{~m}^{3} / 5$ tahun $\mathrm{x}$ Rp. 6000 (Sumber : Tirta Asasta - PDAM Kota Depok)

$=\operatorname{Rp} 46.383 .600$

\section{b. Recycling Water}

Biaya operasional yang dibutuhkan untuk proses pengolahan limbah pada mekanisme pendaur-ulangan air bekas ini ditentukan dari segi per meter kubik. Sehingga biaya yang akan diperlukan 
untuk mendukung operasional proses ini dapat ditentukan sebagai berikut :

- Jumlah total air bekas/air kotor/air

limbah per satuan hari $=80 \mathrm{~m}^{3}$

- Biaya operasional pengolahan air

limbah = Rp.116.133 (asumsi) : 80 $\mathrm{m}^{3}$

$=\mathrm{Rp} 1.451 / \mathrm{m}^{3}$ limbah

Maka bentuk efisiensi yang diperoleh dari mekanisme proses pengolahan diperoleh dari nilai besaran rupiah jumlah total air yang berpotensi dilakukan penghematan dengan digantikannya oleh hasil olahan proses recycling secara rinci ditentukan sebagai berikut :

$=\left(\sum\right.$ air yang di re-use $\mathrm{x}$ Harga air $)-$

Biaya Operasional IPAL

$=\left(80 \mathrm{~m} / 3 /\right.$ hari $\left.\times \mathrm{Rp} .6000 / \mathrm{m}^{3}\right) \quad$ -

Rp.116.133 /hari

= Rp. $480.000-$ Rp. $116.133 /$ hari

$=$ Rp. 363.867/ hari.

$=$ Rp. 10.916.010/ bulan.

= Rp. 130.992.120/tahun.

\section{KESIMPULAN DAN SARAN}

\section{Kesimpulan}

1. Jumlah pemakaian total seluruh penghuni Apartmen sebesar 120.000 liter/hari atau $120 \mathrm{~m}^{3} /$ hari.

2. A.Tower $A$ dengan luas area tangkapan 473,85 m², Tower B 591,6 $\mathrm{m}^{2}$, dan Tower C 473,85 $\mathrm{m}^{2}$.

B.Sementara kapasitas untuk sebuah volume bak air atas bangunan gedung (Roof Tank) sebesar, 17,5 $\mathrm{m}^{3}$. Kapasitas suplai air hujan pada zona $A=68,198 \mathrm{~m}^{3}$, zona $\mathrm{B}=85,146 \mathrm{~m}^{3}$ dan zona $\mathrm{C}=68,198 \mathrm{~m}^{3}$.

3. A. Tahun 2017 diperoleh suplai air hujan 1634,77 $\mathrm{m}^{3}$ (61,491\%).

B. Tahun 2016 diperoleh suplai air hujan 1347,40 m³ (50,682\%).

C. Tahun 2015 diperoleh suplai air hujan 1959,56 m³ (73,708 \%).

D. Tahun 2014 diperoleh suplai air hujan 1345,85 $\mathrm{m}^{3}$ (50,624\%).

E. Tahun 2013 diperoleh suplai air hujan 1443,02 $\mathrm{m}^{3}$ (54,279\%).
4. Distribusi kebutuhan air untuk penghuni apartment sebesar 120 $\mathrm{m}^{3} /$ hari, dengan air buangan $80 \%$ dari $120 \mathrm{~m}^{3} /$ hari yaitu sebesar $96 \mathrm{~m}^{3} /$ hari. Dari limbah atau hasil air buangan yang diperoleh, dipersentasekan dengan nilai $75 \%$ yaitu mencapai 72 $\mathrm{m}^{3} /$ hari dan 25\% merupakan black water sebesar $24 \mathrm{~m}^{3} /$ hari. Air yang berasal dari Kondensasi AC, air buangan (grey water) ditampung kemudian masuk pada unit pengolahan dan digunakan kembali untuk keperluan penggelontoran WC dan Dari system tersebut air yang dihemat (digunakan kembali) yaitu air yang berasal dari buangan (grey water), air kondensasi AC sebesar 96 $\mathrm{m}^{3} /$ hari dan air hujan 22,60 $\mathrm{m}^{3} /$ hari yang ditampung dengan total sebesar $108 \mathrm{~m}^{3} /$ hari volume ground tank 2 sehingga air yang dapat dihemat sekitar $80 \%$ dari total kebutuhan air bersih.

5. A. Penghematan biaya dari konsep Saving Water sebesar Rp Rp 46.383.600

B. Penghematan Air PDAM sebesar 58,157 \% dari total kebutuhan air baku PAH.

C. Effisiensi biaya yang diperoleh dari sistem reuse/recycle ini diperoleh Rp. 363.867/ hari. Rp. 10.916.010/ bulan. Rp. 130.992.120 /tahun.

\section{Saran}

1 Dapat dilakukan penelitian selanjutnya dengan Metode dalam menjaga kestabilan daya dukung tanah dan menjaga permukaan muka air tanah agar tetap stabil dalam Gedung bertingkat.

2 Dapat dilakukan penelitian selanjutnya dengan Optimalisasi bangunan penampung air hujan sebagai pemanfaatan air hujan bagi pemenuhan air baku.

3 Dapat dilakukan penelitian selanjutnya dengan Optimalisasi pengolahan air (Recycling Water) 
dari grey water dan black water menjadi air baku sekunder.

\section{DAFTAR PUSTAKA}

[1] Anna Hurlimann. Recycling water for Australia's future. The Case of two Victorian cities. Faculty of Architecture Building and Planning, The University of Melbourne, Australia.

[2] C. Jason Mabry dan Franca Trubiano. Innovative Sustainable Water Management Practices in Solar Residential Design. 1Georgia Institute of Technology, Atlanta, Georgia.

[3] Dida Prahara. Perencanaan Sistem Plambing Air Bersih Pada Bangunan Kondotel dengan Menggunakan Sistem Gravitasi dan Pompa. Pontianak. Universitas Tanjung pura. Jurnal Teknik Lingkungan.

[4] Ishwar P. Patil, et. 2013. Water Recycle and Reuse - A Case Study of NMIMS University Campus. International Journal of Engineering Science Invention ISSN. India. Volume 2 Issue 9.

[5] Irawan Wisnu Wardhana, dkk. Kajian Sistem Penyediaan Air Bersih Sub Sistem Bribin Kabupaten Gunungkidul. Jurnal Teknik Lingkungan. Universitas Diponegoro. Semarang.

[6] Junia Affiandi, dkk. 2016. Perencanaan Sistem Instalasi Plambing Air Bersih Gedung Hotel Tebu. ITENAS. Jurnal Teknik Lingkungan. No. 2. Vol. 4.

[7] Kementerian Pekerjaan Umum dan Perumahan Rakyat, Direktorat Jenderal Cipta Karya, Direktorat Pengembangan Penyehatan Lingkungan Permukiman. Buku 3 Pembangunan Infrastruktur Sanimas IDB. 2016.
[8] Laxmi C. Gupta dan Samruddhi Thawari. 2016. Plumbing System in High Rise Building. International Journal for Innovative Research in Science \& Technology. India. Vol. 2. Issue 11.

[9] Mayrina Firdayati, dkk. 2015. Greywater in Indonesia : Characteristic and Treatment Systems. Institute of Wastewater Management and Water Protection, Hamburg, Germany.

[10] M.Y.L. Chew, dkk. Grading Maintainability Parameters for Sanitary-Plumbing System for High-Rise Residential Buildings. National of Singapore.

[12] Sandra Madona. 2014. Efisiensi Energi Melalui Penghematan Penggunaan Air: Studi Institusi Pendidikan Tinggi Universitas Bakrie. Jakarta. Jurnal Teknik Sipil. Volume 12. No. 4 : 267-274.

[13] SNI 03-7065-2005 Tata Cara Pelaksanaan Sistem Plambing.

[14] S. Vigneswaran. Recycle and Reuse of Domestic Wastewater. Faculty of Engineering, University of Technology, Sydney, Australia.

[15] Setiyono. 2009. Desain Perencanaan Instalasi Pengolahan Air Limbah (IPAL) dan Re-Use Air di Lingkungan Perhotelan. Pusat Teknologi Lingkungan BPPTeknologi. Jakarta Pusat.

[16] Suhardiyanto. 2016. Perancangan Sistem Plambing Instalasi Air Bersih Dan Air Buangan Pada Pembangunan Gedung Perkantoran Bertingkat Tujuh Lantai. Jurnal Teknik Mesin. Jakarta. Universitas Mercu Buana. Vol. 5. No. 3.

[17] Yushiou Tsai, et. The Impacts Of Water Conservation Strategies On Water Use: Four Case Studies. Journal American Water Resources Association. 